\title{
Article \\ The Role of Soil Moisture Information in Developing Robust Climate Services for Smallholder Farmers: Evidence from Ghana
}

\author{
Samuel J. Sutanto ${ }^{1,2, * \mathbb{D}}$, Spyridon Paparrizos ${ }^{1}\left(\mathbb{D}\right.$, Gordana Kranjac-Berisavljevic ${ }^{3}$, Baba M. Jamaldeen ${ }^{3}$, \\ Abdulai K. Issahaku ${ }^{3}$, Bizoola Z. Gandaa ${ }^{3}$, Iwan Supit ${ }^{1}$ and Erik van Slobbe ${ }^{1}$ (D) \\ 1 Water Systems and Global Change Group, Wageningen University and Research, \\ 6700 AA Wageningen, The Netherlands; spyros.paparrizos@wur.nl (S.P.); iwan.supit@wur.nl (I.S.); \\ erik.vanslobbe@wur.nl (E.v.S.) \\ 2 Institute for Marine and Atmospheric research Utrecht, Utrecht University, 3508 TC Utrecht, The Netherlands \\ 3 West African Centre for Water, Irrigation and Sustainable Agriculture (WACWISA), University for \\ Development Studies, Tamale 1350, Ghana; novagordanak@gmail.com (G.K.-B.); \\ babajamaldeen911@gmail.com (B.M.J.); abdulaiissahaku52@gmail.com (A.K.I.); \\ naa.bizoola1970@gmail.com (B.Z.G.) \\ * Correspondence: samuel.sutanto@wur.nl
}

\section{check for}

Citation: Sutanto, S.J.; Paparrizos, S.; Kranjac-Berisavljevic, G.; Jamaldeen, B.M.; Issahaku, A.K.; Gandaa, B.Z.; Supit, I.; van Slobe, E. The Role of Soil Moisture Information in Developing Robust Climate Services for Smallholder Farmers: Evidence from Ghana. Agronomy 2022, 12, 541. https://doi.org/10.3390/ agronomy12020541

Academic Editor: Angela Libutti

Received: 25 January 2022

Accepted: 17 February 2022

Published: 21 February 2022

Publisher's Note: MDPI stays neutral with regard to jurisdictional claims in published maps and institutional affiliations.

Copyright: (C) 2022 by the authors. Licensee MDPI, Basel, Switzerland. This article is an open access article distributed under the terms and conditions of the Creative Commons Attribution (CC BY) license (https:// creativecommons.org/licenses/by/ $4.0 /$ )

\begin{abstract}
In Ghana, most of the farmers are engaged in small-scale rainfed farming where the success is influenced by the prevailing weather conditions. Current Climate Information Services (CISs) only provide information on rainfall conditions to reduce their farming vulnerability to climate extremes. Access to other practical knowledge, such as soil moisture content would benefit farmers further in the decision-making process. This study aims to assess the role of soil moisture information in farmers' agricultural decision-making and to understand how this information is being perceived, assessed, and applied. Exploratory research, combined with field visits and farmer interviews, was carried out in Gbulung, Napakzoo, and Yapalsi communities in the outskirts of Tamale, northern Ghana in October-December 2021. Results show that soil moisture information is highly important for activities, such as fertilizer application and sowing. Soil moisture information, however, is not readily available to the farmers, causing them to rely solely on their indigenous knowledge to monitor the soil moisture conditions. Our study reveals that developing a CIS embedded with soil moisture advisory module (CIS-SM) will help farmers in conducting strategic and tactical decision-making in their daily farming activities.
\end{abstract}

Keywords: Climate Information Services; smallholder farmers; soil moisture; Ghana

\section{Introduction}

Agriculture across many regions in the global south, such as Africa, Latin America, and South Asia, depend mainly on rainfed agriculture for their staple food production [1]. In Africa over $95 \%$ of agriculture is rainfed [2,3], contributing to $65 \%$ of the employment and $35 \%$ of the gross domestic product (GDP, [4]) on the continent. The agricultural sector provides income security for many African households, and Ghana is not an exception $[5,6]$. The economy of Ghana strongly relies on agricultural production that engages up to 50\% of the country's workforce and generates nearly one-quarter of the nation-wide GDP $[7,8]$. Most of the farmers are engaged in small-scale rainfed farming, where their success is affected by how they are able to match their decisions regarding farming practices to the prevailing weather condition $[9,10]$. Therefore, accessibility of hydro-climatic information services is of utmost importance for sustainable rainfed agricultural practices and leads to higher yields and minimum risk of crop failure [10,11]

Some studies have shown that Climate Information Services (CIS) can help farmers to reduce their vulnerability to drought and other climate extremes and allow them to 
maximize agricultural productivity [12-14]. The underlying assumption in the current practices of CIS is that if location-specific, timely, and skillful information is provided to farmers, they would be able to improve their farming practices [15-17]. This one-directional model of providing CIS, however, has shown to be flawed as farmers tend not to trust scientific information, which is dynamical weather forecasts, and experience difficulties in interpreting and applying the scientific forecasts into daily farming actions. This is also supported by farmers' belief that their indigenous systems work better than the scientific forecasts $[18,19]$. Efforts in training farmers to increase the uptake of CIS generally fail to fully capitalize because service providers have little understanding of users and what drives the use of indigenous forecasts [20-23]. The development of CIS, therefore, must be tailored to smallholder farmers specific needs and involves user training for a better understanding of the required technology [24-27]. Gbangou et al. [27] conducted an experimental coproduction of CIS in Ghana that involved a user-driven design and testing of information and communications technology-based digital tools, such as using smartphones and similar applications. They concluded that the co-production of a CIS promotes Ghanaian farmers with access to as well as better understanding of weather and climate information, leading to improved farming decisions.

Although CISs have been promoted in several countries, the up-to-date CISs, including the FarmerSupport APP (https:/ / play.google.com/store/apps/details?id=com.spacewek. farmersupport accessed on 10 February 2022) only provide information on the recent and forecasted meteorological variables, primarily precipitation and temperature [26-28]. Soil moisture that plays an important role in the soil-plant-atmosphere system is still not well implemented in the currently available CISs. Some studies have documented the importance of soil moisture on agricultural productivity e.g., [29-32]. They concluded that the assessment of soil moisture is crucial to understanding the variability of soil moisture and for optimizing crop production. The plant establishment and growth are directly impacted by the soil moisture content and vice versa, soil moisture is also directly influenced by the vegetation types and structure, causing temporal and spatial variations in its values [33]. These show that soil moisture as a critical and complex variable in the soilplant-atmosphere system is a key component for better agricultural management practices, especially in water-limited areas. For small-holder farmers, as this is the case for Ghana, having access to soil moisture information when practicing rainfed agriculture helps in the decision-making process and managing the effects of extreme weather events on agriculture [34]. Moreover, soil moisture has longer catchment memory than precipitation, leading to higher prediction skill than precipitation, which is essential for developing accurate CIS $[35,36]$.

In this study, we aimed to assess the role of soil moisture in farmers' agricultural decision-making and to understand how this information is being perceived, assessed, and applied for agricultural practices, with a study case in northern Ghana. The ultimate goal of this study is to obtain farmers' perception of the use of soil moisture information in their daily farming practices that will lead to co-production and co-creation of CIS-SM. There are four main research questions addressed in the study: (1) what are the socio-demographic characteristics of farmers participating in this study in the Northern Region of Ghana, (2) what agricultural information do these smallholder farmers receive? (3) how important is this information for their day-to-day farming activities? and (4) what is the role of SM information in agricultural decision-making among small-scale rice farmers in northern Ghana? To answer these questions, we adopted an exploratory research design, combining field visits and farmer interviews including questionnaires [37-39]. These will be described in section two where we present the study location, data, and methods. The results are presented in section three, followed by a discussion on the findings in section four. Finally, we conclude the findings in section five. 


\section{Materials and Methods}

\subsection{Study Area and Site Selection}

Our study was carried out in the Northern Region of Ghana, which is in a tropical Guinea Savannah Agro-Ecological zone, characterized by a single rainy season. This region is ranked as highest in terms of rice production in Ghana and many smallholder farmers engage in rainfed agriculture. A few irrigation schemes in the region also grow rice during rainy season, with supplementary irrigation and vegetables in the dry season [40]. Total annual rainfall is around $1250 \mathrm{~mm}$ [41], with a six-month rainy season in a year, from May to October, and a six-month dry season that ranges from November to April [42]. The unimodal rainfall, other harsh climatic parameters, and poor soils quality negatively affect agricultural production $[43,44]$. Temperature in the northern Ghana is higher, compared to the southern part of the country. The lowest minimum daily temperature is around $15^{\circ} \mathrm{C}$ and is mostly recorded in August, while highest maximum daily temperatures can reach up to $42{ }^{\circ} \mathrm{C}$ and are recorded in March or April, with a mean annual temperature of $28.3^{\circ} \mathrm{C}$ [45]. It is projected that the area will experience a decrease in rainfall frequency, increase in daily temperatures, and increase in rainfall intensity by the year 2050, which may put food security in this region at risk [46].

The field research was conducted in three communities, namely Gbulung in Kumbungu district, and Nakpanzoo and Yapalsi in Savelugu district in the outskirts of Tamale, which is the capital of the Northern Region of Ghana (Figure 1). Field work has been done in the period October-December 2021. Most inhabitants in the Kumbungu and Savelugu districts are of Dagomba ethnic group ( $80 \%$ of the total population), who derive their livelihood from crop farming and livestock rearing, while other ethnic groups, such as Gonja and Ewe, settled in the area and live from fishing industry along the White Volta River [45]. In the Kumbungu district, some farmers also get benefit from the Bontanga decentralized irrigation scheme (470 ha), managed by communities at the local level. The Bontanga irrigation is built on the tributary of the White Volta River with a total discharge of 11 million $\mathrm{m}^{3}$ per annum [47]. Farmers in the Savelugu district also irrigate their farms using water from the tributaries of the White Volta River. In general, there are three groups of farmers in our study areas i.e., those on irrigated farms, rainfed farms, and farmers cultivating both irrigation and rainfed farms. Besides rice, other crops, such as maize, pepper, soybean, and groundnuts, are cultivated in Kumbungu and Savelugu districts.

The vegetative cover is typical of Guinea Savanna with isolated trees and tall grass. The soil generally consists of the sandy loam type, except in the lowlands, where alluvial deposits are found. Subsistence agricultural production is the main economic activity of the districts and is highly seasonal. The trees found in the area are drought resistant and hardly shed their leaves completely during the long dry season. Most of these are of economic value and serve as important means of livelihood, especially for women. Notable among these are Shea trees (Vitellaria Paradoxa, used for making shea butter) and Dawadawa (Parkia Biglobosa), that provides seeds used for condimental purposes and many other locally used products [48].

\subsection{Data Collection}

The primary data were collected through reconnaissance field visits, participatory interaction with farmers, and semi-structured personal interviews and questionnaires (see Supplementary Materials) with a total of 49 farmers located in three communities, namely Gbulung (16 farmers), Nakpanzoo (17 farmers), and Yapalsi (16 farmers). Interview and questionnaire consist of questions related to demographic information of farmers, the availability of water including soil moisture, weather, and agricultural-related information, and indigenous knowledge. Moreover, we also asked farmers about information needs for agricultural decisions making and the availability of water and weather forecast data. The latter was focused more on the soil moisture information availability from different sources as perceived by farmers. The evidence collected helped to understand the need for soil moisture information in the selected farmers' group. 
We collected soil data by taking soil samples to the laboratory for future use and also carried out gender segregated focus groups (FGD) to discuss the importance of soil moisture and to train farmers on how to estimate soil moisture on the field, using the feel and appearance method [49]. The FGDs are still on going and will finish at the end of rainy season in the year 2022. The outcome of the FGDs will be presented as endline study after all the FGDs and trainings are completed e.g., [23].

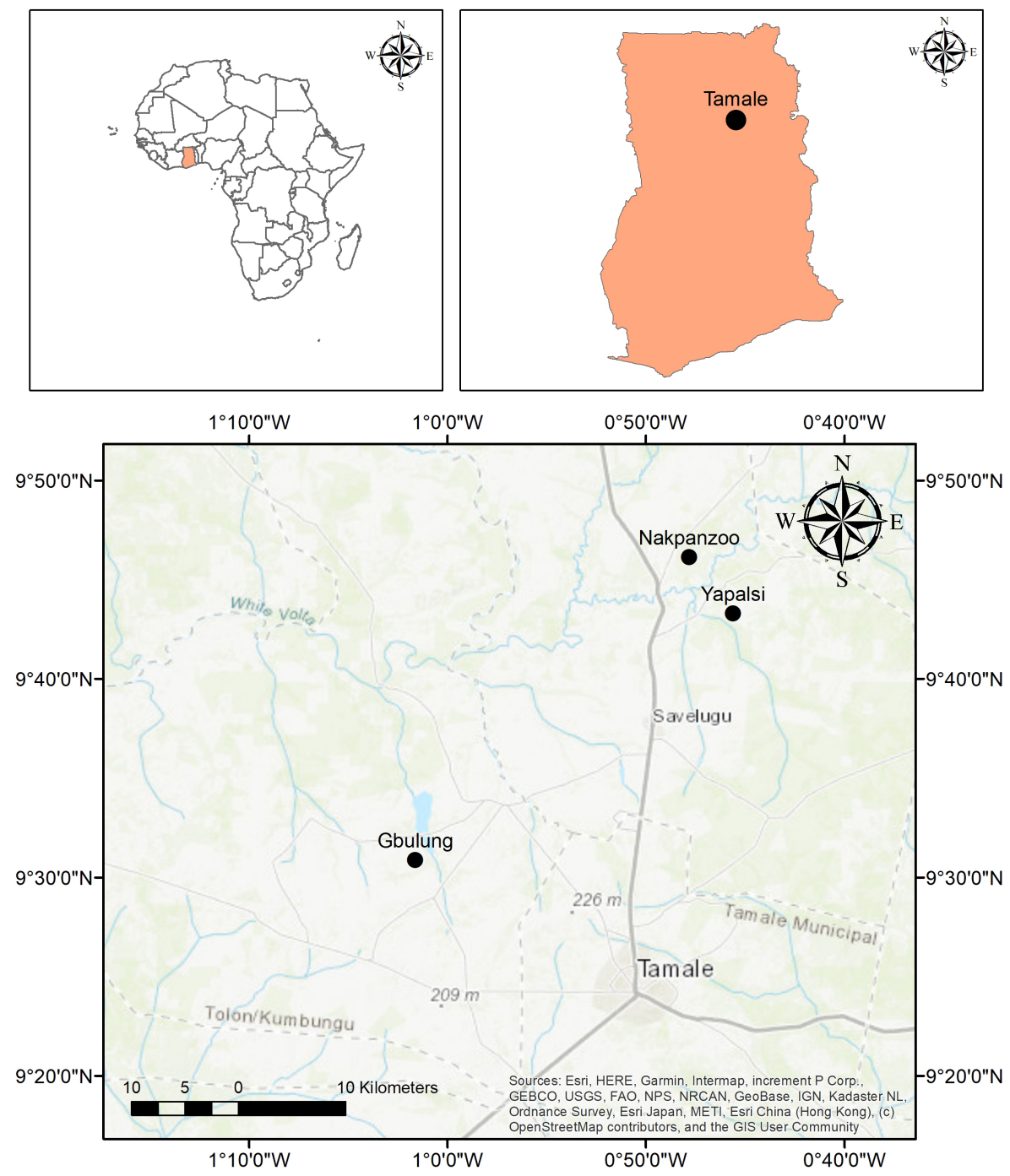

Figure 1. Map showing locations of the study area in northern Ghana. Gbulung community is located in the Kumbungu district, northwest of Tamale, the regional capital, while Nakpanzoo and Yapalsi communities are located at the Savelugu district north of the Tamale.

\subsection{Data Analysis}

In this study, exploratory research approach [37,38] involving survey, interviews, and group discussions was adopted. We believe that soil moisture provides valuable information that is strongly related to crop growth in addition to climate. Thus, we used exploratory research to gain insight into how soil moisture information is being perceived, assessed, and applied for daily agricultural practices. We applied the purposive sampling method, also called judgment sampling, in selecting the farmers for interviews, group discussions, and training [50,51]. In each community, we have tried to include female farmers as much as possible to achieve gender balance among respondents.

Data analysis was performed in two stages, first translating the data from interviews and questionnaires to an excel spreadsheet for further analysis and second, interpreting the 
data into key themes of interest. All figures were plotted using Python 3.7 software. We grouped the themes into five sections, e.g., 3.1 to 3.5. Translating data included cleaning information from interviews and questionnaires, transcribing the audio recordings, and editing field notes [52,53]. Interpretation of the data was based on how information was perceived by the farmers. For that reason, farmers were asked to consider how their answers reflect the available information in the existing systems and their needs.

\section{Results}

\subsection{Socio-Demographic Characteristics of Respondents}

Analysis of farmer's characteristics, such as gender, age, household size, education, land ownership, animal husbandry, off-farm income, and the farming experience was carried out for each community (Table 1). We conducted interviews with 16-17 farmers in each community to get an equal number of respondents. Although we have tried hard to get gender balance in the respondents, 4 or less female farmers participated, with the highest female participation in Gbulung ( 4 female farmers), followed by Yapalsi ( 3 female farmers) and Nakpanzoo ( 2 female farmers). The main reason is that farming activities in this part of Ghana are dominated by men [54]. Men are responsible for land preparation. Planting is sometimes done by both men and women while fertilizer and pesticide application are male jobs. Women normally do weeding and sometimes it is executed more than once. Harvesting is carried out manually using sickle, where women also take part or by rented machinery. Winnowing is a women's job as well as parboiling and marketing. If woman has a farm, which is usually given by male relative, she will hire men to do operations described as male above. Another reason is that women have limited access to land, labor, and capital due to cultural, societal, and institutional restrictions [55,56]. A study by FAO [57] also shows a significant gender disparity in land holdings, with male farmers having 3.2 times more small farms than females and 8.1 times more medium to large farms (of 5 acres and more).

Most participants' have age ranging from 35 to 44 years old, which is represented by 5 farmers in each community. The highest number of older farmers with age groups ranging from 55 to 64 years old is found in Yapalsi ( 3 farmers). In general, farming activities are dominated by farmers aged 25 to 54 years old, which are of the working-age category [58]. In terms of household size, there is a difference in the number of households in each community. In Gbulung, many households have a number of people between 6 and 13 (8 respondents) while the majority of households in Napakzoo have between 6-9 people (6 respondents) and either 14 to 17 or $>21$ people in Yapalsi (5 respondents each). The average household size in our study areas is 12 people, comparable to other studies in the study area [59]. The education level of farmers varies from no formal education (illiterate) to tertiary education level. More than $50 \%$ of farmers ( $>8$ respondents) in three communities are illiterate, which is comparable to the statistics for the district of $69.2 \%$ [60].

In Gbulung and Yapalsi, less than half of the interviewed farmers work on their own farms but rather on the farms that belong to their household or clan head. Many of them also do animal husbandry, mainly rearing sheep and goat ( $>12$ respondents). The non-ownership of farmland in these communities might explain the high number of respondents that are also working in the off-farm and non-farm sectors as their side jobs, such as carpenters, butchers, mobile money agents, storekeepers, fishermen, and traders ( $>10$ respondents). It is vice versa situation in Nakpanzoo, where around 13 farmers work on their own farms and only 5 farmers have side jobs as bread sellers, butchers, teachers, and masons. This indicates that farmers who do not have their own farms tend to have secondary jobs outside farming activities. Similar to Gbulung and Yapalsi, more than 13 farmers in Nakpanzoo do animal husbandry rearing mostly small ruminants. The experience in farming differs across three communities. The less experienced farmers (10 farmers) are found in Gbulung, with experience in farming mostly less than 10 years. Whereas the most experienced farmers are found in Yapalsi (more than 20 years of experience, counted from 7 farmers). Most farmers in Nakpanzoo (7 farmers) have farm experience between 11-20 years. 
Table 1. Characteristics of the respondents.

\begin{tabular}{|c|c|c|c|c|c|c|c|c|}
\hline \multicolumn{3}{|c|}{ Gbulung } & \multicolumn{3}{|c|}{ Nakpanzoo } & \multicolumn{3}{|c|}{ Yapalsi } \\
\hline Variable & $N=16$ & $\%$ & Variable & $\mathbf{N}=17$ & $\%$ & Variable & $\mathbf{N}=16$ & $\%$ \\
\hline \multicolumn{3}{|l|}{ Gender } & \multicolumn{3}{|l|}{ Gender } & \multicolumn{3}{|l|}{ Gender } \\
\hline Male & 12 & 75 & Male & 15 & 88.2 & Male & 13 & 81.3 \\
\hline Female & 4 & 25 & Female & 2 & 11.8 & Female & 3 & 18.8 \\
\hline \multicolumn{3}{|l|}{ Age } & \multicolumn{3}{|l|}{ Age } & \multicolumn{3}{|l|}{ Age } \\
\hline$<25$ & 3 & 18.8 & $<25$ & 0 & 0 & $<25$ & 3 & 18.8 \\
\hline $25-34$ & 5 & 31.3 & $25-34$ & 5 & 29.4 & $25-34$ & 1 & 6.3 \\
\hline $35-44$ & 5 & 31.3 & $35-44$ & 5 & 29.4 & $35-44$ & 5 & 31.3 \\
\hline $45-54$ & 3 & 18.8 & $45-54$ & 5 & 29.4 & $45-54$ & 4 & 25 \\
\hline $55-64$ & 0 & 0 & $55-64$ & 2 & 11.8 & $55-64$ & 3 & 18.8 \\
\hline \multicolumn{3}{|c|}{ Household size } & \multicolumn{3}{|c|}{ Household size } & \multicolumn{3}{|c|}{ Household size } \\
\hline $2-5$ & 1 & 6.3 & $2-5$ & 1 & 5.9 & $2-5$ & 0 & 0 \\
\hline $6-9$ & 4 & 25 & $6-9$ & 6 & 35.3 & $6-9$ & 3 & 18.8 \\
\hline $10-13$ & 4 & 25 & $10-13$ & 2 & 11.8 & $10-13$ & 0 & 0 \\
\hline $14-17$ & 1 & 6.3 & $14-17$ & 1 & 5.9 & $14-17$ & 5 & 31.3 \\
\hline $18-21$ & 4 & 25 & $18-21$ & 2 & 11.8 & $18-21$ & 3 & 18.8 \\
\hline$>21$ & 2 & 12.5 & $>21$ & 5 & 29.4 & $>21$ & 5 & 31.3 \\
\hline \multicolumn{3}{|l|}{ Education } & \multicolumn{3}{|l|}{ Education } & \multicolumn{3}{|l|}{ Education } \\
\hline Illiterate & 8 & 50 & Illiterate & 9 & 52.9 & Illiterate & 10 & 62.5 \\
\hline Basic & 3 & 18.8 & Basic & 6 & 35.3 & Basic & 3 & 18.8 \\
\hline JHS & 1 & 6.3 & JHS & 1 & 5.9 & JHS & 1 & 6.3 \\
\hline SHS & 3 & 18.8 & SHS & 1 & 5.9 & SHS & 0 & 0 \\
\hline Tertiary & 1 & 6.3 & Tertiary & 0 & 0 & Tertiary & 2 & 12.5 \\
\hline \multicolumn{3}{|c|}{ Land ownership } & \multicolumn{3}{|c|}{ Land ownership } & \multicolumn{3}{|c|}{ Land ownership } \\
\hline Yes & 7 & 43.8 & Yes & 13 & 76.5 & Yes & 7 & 43.8 \\
\hline No & 9 & 56.3 & No & 4 & 23.5 & No & 9 & 56.3 \\
\hline \multicolumn{3}{|c|}{ Animal farm } & \multicolumn{3}{|c|}{ Animal farm } & \multicolumn{3}{|c|}{ Animal farm } \\
\hline Yes & 13 & 81.3 & Yes & 14 & 82.4 & Yes & 12 & 75 \\
\hline No & 3 & 18.8 & No & 3 & 17.6 & No & 4 & 25 \\
\hline \multicolumn{3}{|c|}{ Off-farm income } & \multicolumn{3}{|c|}{ Off-farm income } & \multicolumn{3}{|c|}{ Off-farm income } \\
\hline Yes & 10 & 62.5 & Yes & 5 & 29.4 & Yes & 11 & 68.8 \\
\hline No & 6 & 37.5 & No & 12 & 70.6 & No & 5 & 31.3 \\
\hline \multicolumn{3}{|c|}{ Farm experience } & \multicolumn{3}{|c|}{ Farm experience } & Farm exper & nce & \\
\hline $1-10$ year & 10 & 62.5 & $1-10$ year & 5 & 29.4 & $1-10$ year & 5 & 31.3 \\
\hline 11-20 year & 5 & 31.3 & 11-20 year & 7 & 41.2 & 11-20 year & 4 & 25 \\
\hline$>20$ year & 1 & 6.3 & $>20$ year & 5 & 29.4 & $>20$ year & 7 & 43.8 \\
\hline
\end{tabular}

\subsection{The Available Weather and Water-Related Agricultural Information}

Most farmers in the studied communities claimed that they have access to agricultural information that plays role in their farming decision-making (46 farmers). They have received information primarily from radio (36 respondents), followed by television (TV, 21 respondents), extension agents (18 respondents), peer farmers (17 respondents), Non Governmental Organizations (NGOs, 10 respondents), and through mobile phone (6 respondents) (Figure 2a). Each farmer can choose from more than one source of information, which explains the total of respondents for more than 49 respondents. Radio was chosen as the main source of information because community radio was specifically developed to create a platform for information sharing and discussion related to the local agricultural economy. Commercial radio, on the other hand, provides limited agricultural information, which comprises only $10 \%$ of the station's programs [25]. This indicates that community radio plays an important role in disseminating agricultural information in Ghana. Although 46 farmers either owned mobile phones or have at least one family member who owned a phone, only 6 farmers claim that they receive agricultural information via mobile phone. 

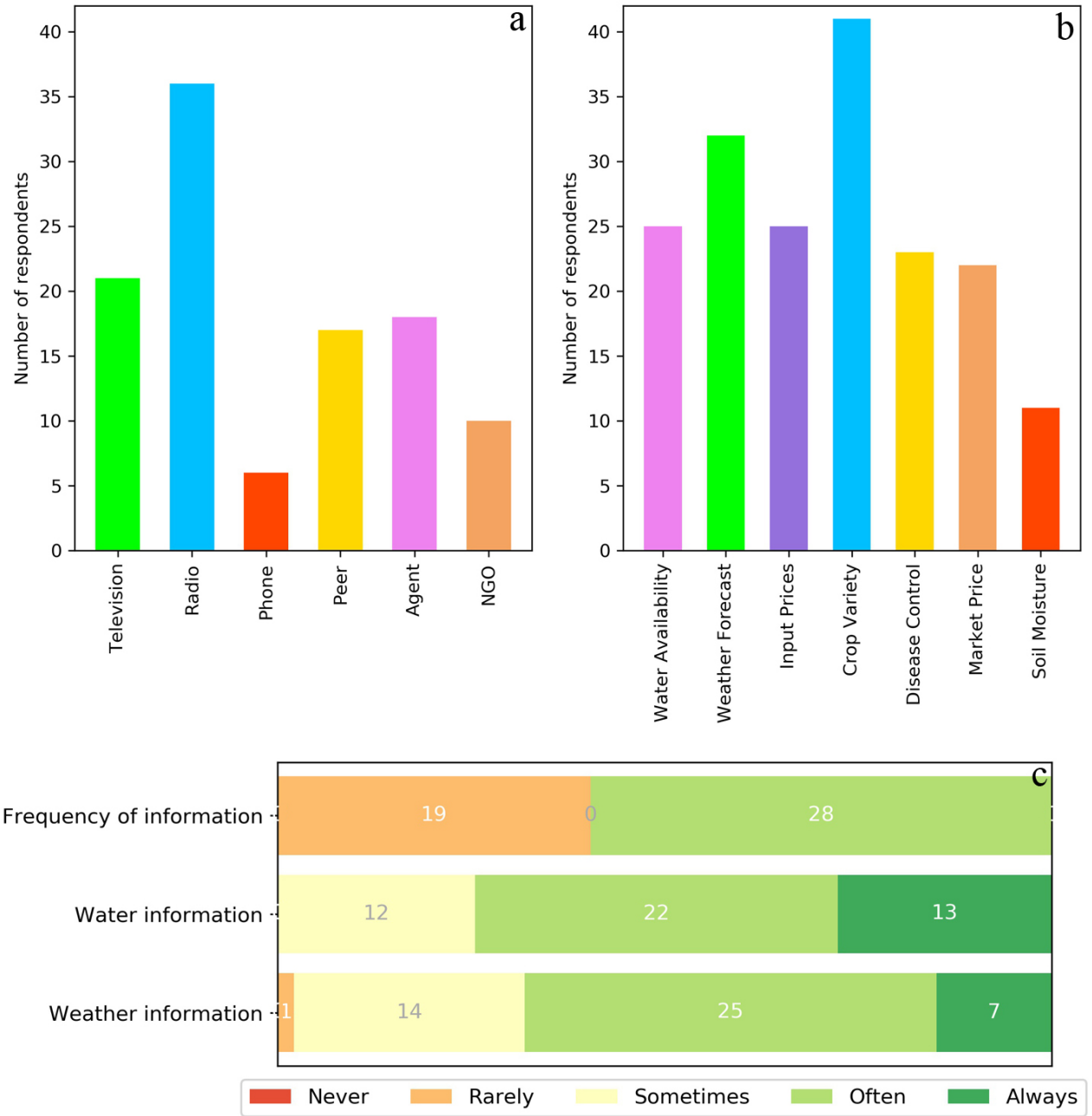

Figure 2. Agricultural-related information received by the smallholder farmers and their dependency on weather and water information for farming decision-making. (a) Source of information, (b) type of information, (c) frequency of information received by farmers, dependency on water (mainly runoff and residual water content) and weather information.

We also noticed that information on crop variety is the most received type of information in the three communities, obtained from different sources (41 respondents, Figure $2 b$ ). Weather forecasts are placed second, claimed by 32 respondents, followed by water availability (25 respondents), input prices ( 25 respondents), disease control ( 23 respondents), market price (22 respondents), and soil moisture (11 respondents). Water availability means runoff from higher parts of the valley into the rice farms and also residual soil moisture. Here, it is clearly seen that soil moisture status as the key variable for plant growth is not well disseminated to farmers. More than 29 respondents stated that they do not always obtain agricultural-related information (Figure 2c). Figure 2c also shows the dependency of farmers on water and weather information for agricultural decision-making. The majority of farmers reported that they either always or often depend on the water and weather information (35 and 32 respondents, respectively). None of the farmers stated that they do not depend on the water information and only one farmer stated that he rarely depends on the weather information. Figure $2 \mathrm{c}$ clearly indicates the need for water and weather information for agricultural decision-making but this information is not well distributed.

Figure 3 shows the farmers' perception of the quality of weather and water information and the significance of this information for their daily farming activities. We grouped farmer perception based on the importance. Many farmers declared that information on water availability and the weather forecast is important, with a total of 38 and 42 respondents, 
respectively, and none of the farmers declared this information is not important to them (Figure 3a). Total respondents for each variable are less than 49 farmers, because several farmers did not provide an answer. The quality of water availability information, in general, is good and excellent as it was claimed by 14 and 15 farmers, respectively (Figure 3b). More than 20 respondents said that the quality of the weather forecast is good. Only 8 farmers stated that the quality of the weather forecast is excellent.
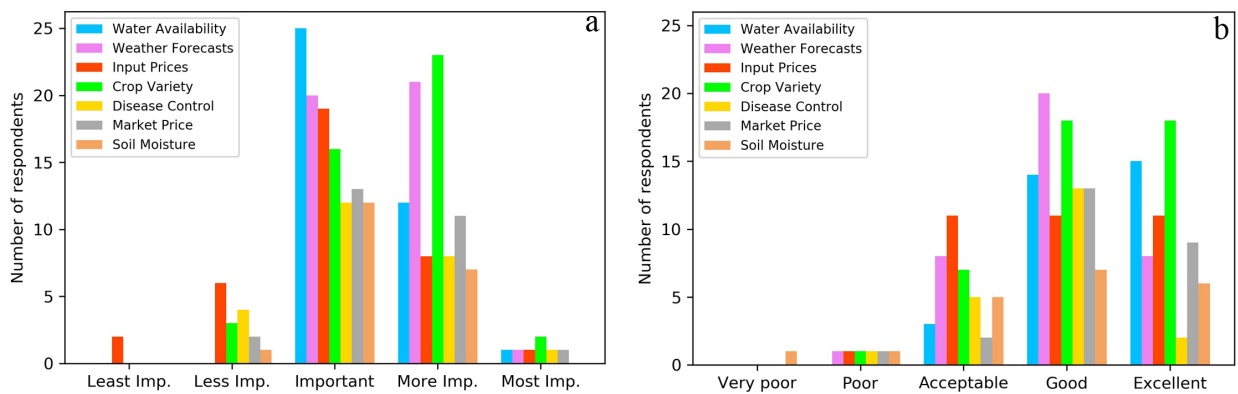

Figure 3. Farmer perception on (a) the importance of weather and water-related information and (b) the quality of weather and water-related information. Acronym Imp stands for important.

Crop variety and input price were chosen as the second group of important information by farmers, after water availability and weather forecast (Figure 3a). From a total of 44 farmers, $93 \%$ of farmers said that information on crop variety is important. However, only $78 \%$ of farmers (28 farmers out of a total of 36 respondents) said that input price information is important, which shows the lowest percentage of farmers chosen for important information after disease control ( $84 \%$ or 21 out of total 25 respondents). Information regarding input price and crop variety has good and excellent quality, as declared by 22 (65\% of respondents) and 36 farmers ( $82 \%$ of respondents), respectively (Figure $3 \mathrm{~b}$ ). Soil moisture was only selected by 19 farmers as important information in agricultural decision-making, which is the lowest, compared to others. Result indicates that farmers lack awareness of the importance of soil moisture in agricultural practices.

\subsection{The Available Soil Moisture Information Related to Agriculture}

In the previous section, only a few farmers stated that soil moisture is an important variable for farming decision-making. However, in farmers examination regarding their awareness of the soil moisture concept, all participants confirmed that they are aware of the concept of soil moisture. More than half of the farmers (29 respondents) do soil moisture measurement by feeling the soil by the hand and smelling the soil (Figure 4). Half of the farmers (24 respondents) measure the soil moisture at the root zone and the rest at the surface. In general, farmers measure the soil moisture by several methods, such as touching the ground if it is wet or dry, squeezing the soil to extract water from the soil, measuring the stickiness of the soil, and using the cutlass method. These methods, however, will only give an indication of the dryness or wetness of the soil and not details required for more precise decisions in farming. 
a
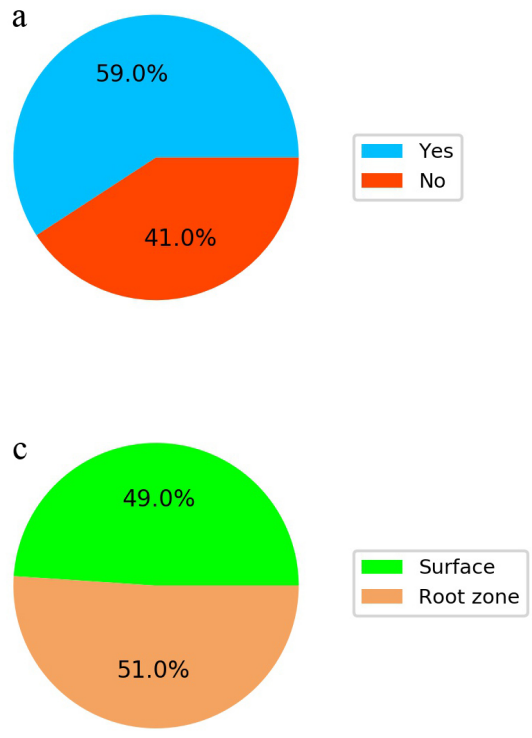

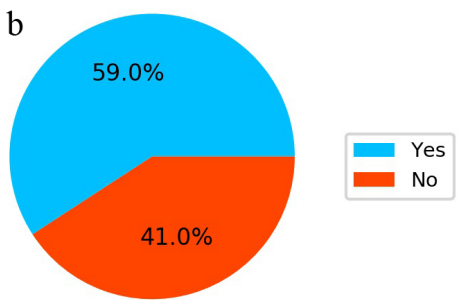

Figure 4. Information related to soil moisture measurement: (a) percentage of farmers measures soil moisture by feeling, (b) percentage of farmers measures soil moisture by smell, and (c) depth of measurement.

About 46 respondents use soil moisture information obtained from their own measurements and from other sources, such as NGOs, extension agents, and peer farmers as an indicator for agricultural activities at various stages in rice production. In general, farmers declared that soil moisture information is significantly important in almost each rice production stage. During land preparation, about 21 and 16 respondents feel that information of soil moisture is very important and important, while information on soil moisture is even very and extremely important during sowing as it was said by 23 and 17 farmers, respectively (Figure 5). For fertilizer application, more than half of the respondents (26 respondents) stated that information on soil moisture is very important, and 15 respondents stated extremely important. A higher number of farmers indicated that soil moisture information is important and very important for weed control and to determine the rice varieties, with a total number of respondents of 39 and 30, respectively. The majority of the farmers (24 respondents) do not know the importance of soil moisture in pest control. At the harvesting stage, 19 farmers indicated that soil moisture information is important, and 17 farmers indicate that it is not important.

\subsection{The Importance of Forecast Information and the Needs}

In this section, farmers' perception of the importance of forecast information was evaluated. 28 farmers agreed that forecast information is needed and 17 farmers stated that forecast information is indispensable (Figure 6a). The majority of the farmers (21 respondents) are interested in receiving forecast information with a lead-time of two to three days in advance while 8 farmers demand forecast information with a lead-time of one day and one month in advance (Figure $6 b$ ). Figure $6 c$ shows forecast information needs of smallholder farmers in the three communities. As expected, almost all farmers (47 respondents) require rainfall forecast information. Information on soil moisture forecast is placed as the second demanded forecast, with 43 farmers opting for this information. 30 farmers are interested in temperature forecasts while only 8 and 3 farmers opt for humidity and storm forecasts, respectively. Here, our results agree well with Kumar et al. [23] where rainfall and temperature forecasts are mostly demanded by the farmers. The frequent natural disasters that challenge the farming activities in the study regions are flood and drought (interview results, 2021). 


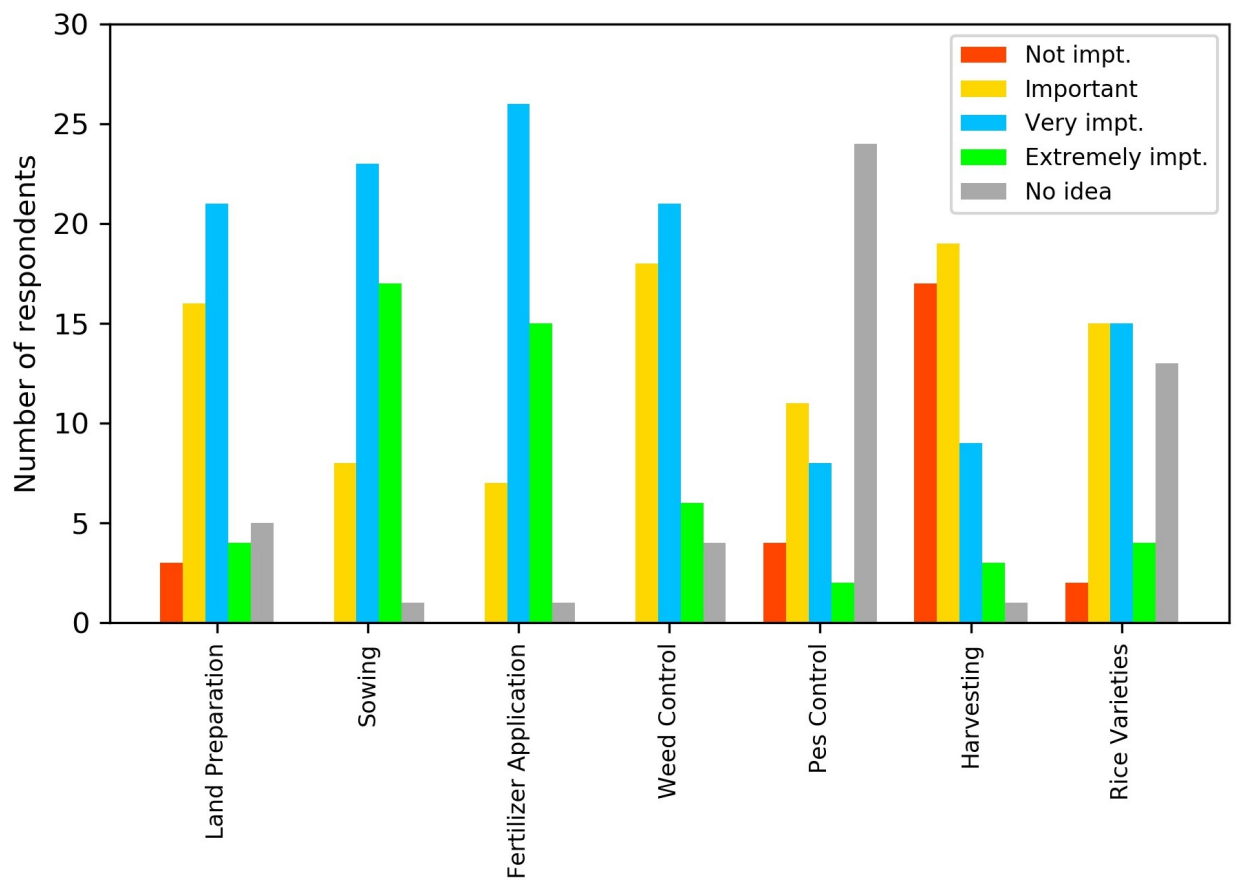

Figure 5. Farmers' perception on the importance of soil moisture in farming decision-making stages. Acronym impt stands for important.

Table 2 shows the number of respondents receiving soil moisture information, the importance of soil moisture information, the farming decision stage, and the importance of soil moisture forecast in each community. Only a small number of farmers in Gbulung receive soil moisture information and therefore, farmers in this community do not feel that soil moisture information including forecast is important. On the contrary, many farmers in the Yapalsi, who receive soil moisture information, stated that soil moisture information is important. Many of them also indicate the importance of soil moisture forecast. Our result shows that the more farmers receive soil moisture information, the more important soil moisture information and forecast are to them.

Table 2. Soil moisture information received by farmers and the importance of soil moisture in each community.

\begin{tabular}{|c|c|c|c|c|c|}
\hline No & Variable & Gbulung & $\begin{array}{l}\text { Community } \\
\text { Nakpanzoo }\end{array}$ & Yapalsi & Unit \\
\hline 1 & Altitude & 139.0 & 115.4 & 117.0 & $\mathrm{~m}$ \\
\hline 2 & Soil type & sand, silt & sand, silt & sand, silt & - \\
\hline 3 & $\begin{array}{l}\text { Farmer received } \\
\text { SM information }\end{array}$ & 6.3 & 29.4 & 31.3 & respondents \\
\hline 4 & $\begin{array}{l}\text { Importance of SM } \\
\text { information }\end{array}$ & 31.3 & 35.3 & 50.0 & respondents \\
\hline 5 & $\begin{array}{l}\text { Farming decision } \\
\text { stage }\end{array}$ & Fertilizer & Sowing & Sowing & - \\
\hline 6 & $\begin{array}{l}\text { Importance of SM } \\
\text { forecast }\end{array}$ & 81.3 & 88.2 & 93.8 & respondents \\
\hline
\end{tabular}


a

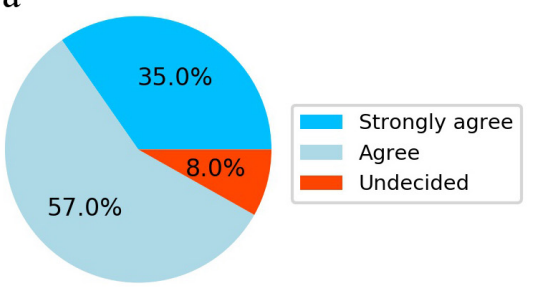

b

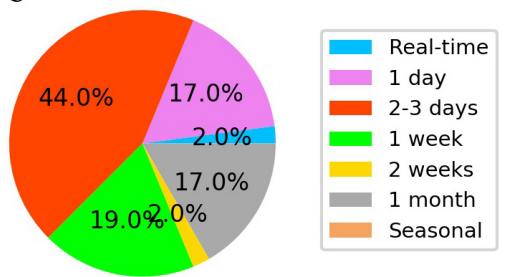

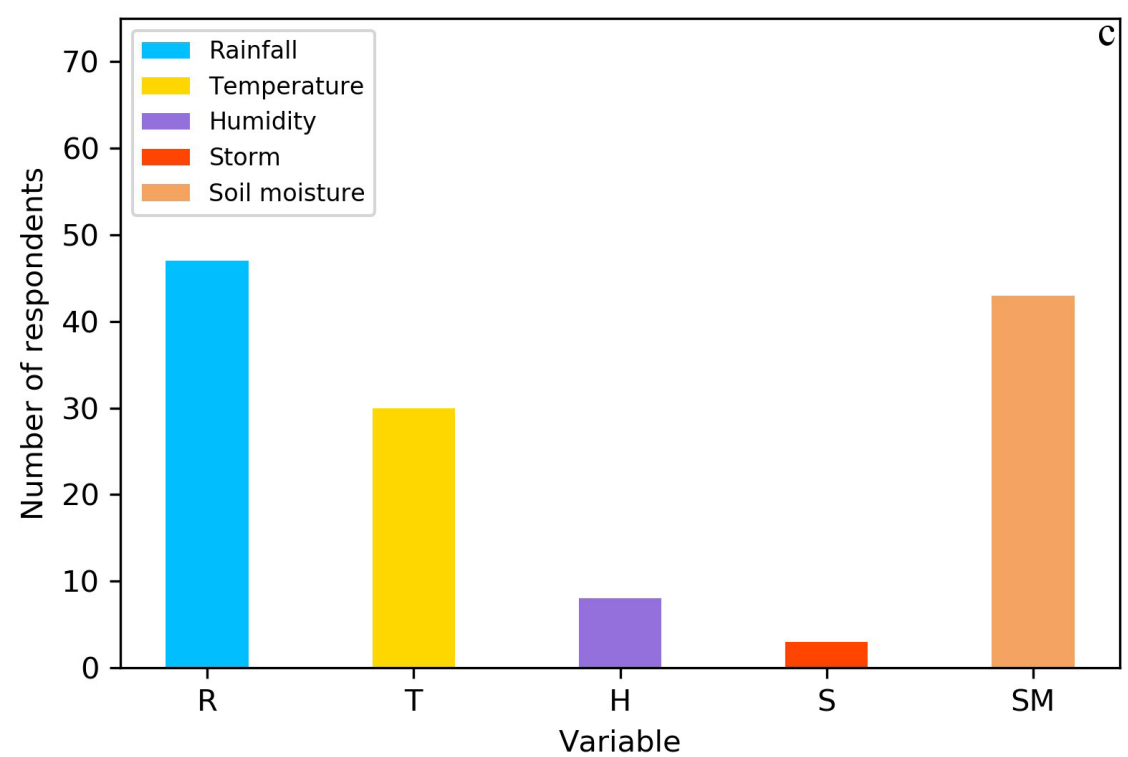

Figure 6. (a) Farmer's perception on the importance of forecast information, (b) the percentage of forecast lead-time needs by smallholder farmers, and (c) forecast variable needs of smallholder farmers. R stands for Rainfall, $\mathrm{T}$ stands for Temperature, $\mathrm{H}$ stands for humidity, $\mathrm{S}$ stands for storm, and SM stands for soil moisture.

\subsection{The Indigenous Soil Moisture Knowledge}

During interviews, farmers listed some indigenous agro-meteorological indicators based on insect behavior and meteorological parameters, such as intense heat, wind, mosquito, ants, and caterpillars. Some local indicators to predict rainfall occurrences are described as follows: the occurrences of intense heat, the wind blowing towards the East, many mosquitoes appearing, and ants carrying eggs uphill indicate that a rainy event is foreseen in hours. The presence of caterpillars means that rain might stop for a while. One farmer mentioned that drought might occur if they see snails seal their shells. We can relate the prediction of rain events to wet soil and vice versa for drought. Based on interviews, nevertheless, farmers indicate how they monitor the soil moisture condition using the indigenous knowledge.

Table 3 presents several indigenous indicators used by farmers to monitor local soil moisture conditions. These indicators were collected based on explicit interviews and discussions focused on soil moisture with experienced local knowledge farmers (only a few of them). Here, farmers use indicators based on plants and animals to indicate the status of the soil and relate them with agricultural activities. Four plant species and one animal were mentioned by the farmers during interviews. If they see small animals (e.g., cat) that can completely hide behind the Gbingbane plant at the start of the rainy season, then sowing/planting activities can be carried out. Another indicator for sowing activity is by observing the fruits of the Shea tree. When the Shea fruit starts ripening, then it indicates a good time for sowing. Observing a Karifi Maalam plant is useful to determine 
the specific types of crops for planting (i.e., groundnuts, maize, and rice) while sowing any type of crop can be performed based on an observation of the Dawadawa tree. The presence of earthworms indicates a good timing for sowing, associated with the prediction of a rain event.

Table 3. Documentation of local indicators to monitor soil moisture conditions.

\begin{tabular}{|c|c|c|c|c|}
\hline No & Name of Indicator & Indicator Signal & Period/Month & SM Status \\
\hline 1 & $\begin{array}{l}\text { Gbingbane plant (at matu- } \\
\text { rity stage) }\end{array}$ & $\begin{array}{l}\text { When poultry, or small an- } \\
\text { imals (cat) can hide be- } \\
\text { hind shrub without being } \\
\text { seen }\end{array}$ & $\begin{array}{l}\text { Onset of the rainy season } \\
\text { (April/May) }\end{array}$ & $\begin{array}{l}\text { Soil ready for sow- } \\
\text { ing/planting }\end{array}$ \\
\hline 2 & $\begin{array}{l}\text { Shea tree (Vitellaria para- } \\
\text { doxa) }\end{array}$ & $\begin{array}{l}\text { Immediately after the } \\
\text { fruits start ripening }\end{array}$ & $\begin{array}{l}\text { Onset of the rainy season } \\
\text { (April/May) }\end{array}$ & $\begin{array}{l}\text { Soil ready for sow- } \\
\text { ing/planting }\end{array}$ \\
\hline 3 & Karifi maalam plant & $\begin{array}{l}\text { 1. When it starts to fruit, } \\
\text { 2. When its fruits starts } \\
\text { ripening. From the start } \\
\text { of ripening to fully ripe } \\
\text { fruits }\end{array}$ & Rainy season (May/June) & $\begin{array}{l}\text { 1. Good for sowing of } \\
\text { groundnuts and maize, } 2 \text {. } \\
\text { Good for planting of rice }\end{array}$ \\
\hline 4 & $\begin{array}{l}\text { Dawadawa tree (African } \\
\text { Locust tree-Parkia biglo- } \\
\text { bosa) }\end{array}$ & $\begin{array}{l}\text { Immediately when har- } \\
\text { vest of ripe fruits starts }\end{array}$ & $\begin{array}{l}\text { Rainy season (May to } \\
\text { June/July) }\end{array}$ & $\begin{array}{l}\text { Suitable for any type of } \\
\text { crop }\end{array}$ \\
\hline 5 & Presence of Earth worms & $\begin{array}{l}\text { Earth worms on the earth } \\
\text { surface after it rained indi- } \\
\text { cate effective rainfall }\end{array}$ & Rainy season & $\begin{array}{l}\text { Soil is suitable for sow- } \\
\text { ing since moisture is re- } \\
\text { lated to rainfall }\end{array}$ \\
\hline
\end{tabular}

\section{Discussion}

\subsection{Opportunities to Develop Mobile-Based CIS}

Many farmers in the Gbulung, Nakpanzoo, and Yapalsi communities located in the northern region of Ghana indicated that they receive agricultural-related information mainly from radio (total of 36 respondents, Figure 2). Our study also shows that $94 \%$ of farmers (46 respondents) interviewed have access to mobile phones. However, only around 6\% (6 respondents) receive agricultural information via mobile phone. We then pursued more detailed information about mobile phones use, such as Short Message Services (SMS), phone calls, and apps to obtain agricultural information. It turns out that $35 \%$ of respondents (17 respondents) obtain agricultural information by receiving SMS and call from agricultural extension officers and no one uses the apps and internet. A similar conclusion is found in central Kenya where $98 \%$ of farmers own a mobile phone but only around $25 \%$ of farmers use the mobile phone to access information about agriculture and livestock [61]. This condition is contradicted with Kumar et al. [23,62] study in Bangladesh. In their studies, $54 \%$ of farm households have access to smartphones but more than $50 \%$ of farmers prefer information and communications technology (ICT)-based platforms (e.g., smartphones and apps). In addition, a study by Gbangou et al. [54] in Ada East district Ghana also concluded that the use of ICT-based tools such as smartphone apps is highly relevant for dissemination of forecast data. In general, results from those studies show the need for ICT-based tools including CIS for improving agricultural decision-making and reducing climate-related risks.

The high number of farmers who owned mobile phones in our study areas and elsewhere in the world opens a new opportunity for mobile-based CISs in agricultural decision-making. This is supported by large-scale investment in ICT infrastructures across Africa, the drop in smartphone cost, and better telecommunication connectivity and internet access in rural areas $[63,64]$. Climate Information Services have the potential to complement the currently inadequate/less effective extension services, especially to ensure that smallholder farmers have access to agricultural-related information [65]. The developed CIS, however, must be tailored to smallholder farmers specific needs, involving co-production 
and co-creation of information systems and followed by the end-user training for a better understanding of the required technology [24-27].

\subsection{The Needs for Weather and Water-Related Agricultural Information}

Our results clearly indicate the need for water and weather information for agricultural decision-making among farmers but this information is not well disseminated (Figures 2 and 3). More than 28 respondents confirmed the importance of water and weather information in their daily farming activities and none reported this as not important. Besides, farmers also need advisory services and other information such as input prices, crop variety, disease control, market price, and soil moisture for precise agricultural decision-making e.g., [66-68].

The majority of the farmers ( 21 respondents) reported that they prefer information on weather and water forecasts with a lead-time of two days to three days in advance (Figure 6b). Our results differ from previous studies in Northern Ghana showing that the most desirable forecast lead-time is one month $[69,70]$. They argue that one month leadtime can significantly inform farmer decision-making as part of preparatory arrangements before the season begins. A lead-time of three months is of least relevance for farmers because of much greater variation in expected seasonal conditions and also the fact that the majority of farmers do not consider farming activities three months in advance, as this is also found in our study. A baseline study conducted by Kumar et al. [23] in Bangladesh concluded that more than $40 \%$ of the farmers in the lower Bengal delta demanded weather forecasts with lead-times of one week and two weeks. In our study regions, one week and two weeks forecast lead-times are only required by $19 \%$ (9 respondents) and $2 \%$ of the farmers (1 respondents), respectively.

The short forecast lead-time chosen by farmers is practical for daily farming activities. However, it is too short for strategic agricultural decision-making and management. For example, when the soil is slightly moist and the three days forecast predicts no foreseen rain events, farmers might apply fertilizer. Yet, the fertilizer application is not optimal if rain occurs on the fourth day, which will wash away the fertilizer from the soil. Here it should be noted that farmers in our study areas are not familiar with forecast time scales for more than one week, as indicated earlier. Many farmers receive agricultural information including forecasts from radio and TV (Figure 2a), with a lead time of up to three days [28]. The use of weekly, bi-weekly, and one month forecasts is suggested for better agricultural decision-making although traditional farmers usually do not take decisions for more than one to two weeks in advance [23,70]. Three months or (sub)seasonal forecast will be useful for strategic agricultural planning such as the selection of a more profitable crop variety that fits well with the forecasted seasonal weathers, either drier or wetter than normal in the coming months. The choice of the forecast lead-time also needs to consider the accuracy of the forecast. The weather forecasts have higher skill for short lead-time and the skill deteriorates with longer lead-time [71,72]. FGD and training will hopefully increase the awareness of farmers on forecast lead-time and may change farmers' perspectives on the need for soil moisture information.

Soil moisture as one of the most important variables that strongly influence plant establishment and growth was only selected by 19 farmers (39\%) as important information in agricultural decision-making (Figure 3). Lack of soil moisture information received by the farmers is conjectured as the main reason why soil moisture information is less important variable when it comes to agricultural decision-making compared to others (see also Table 2). Almost all farmers (43 respondents) demanded soil moisture forecast information, after rainfall forecast (47 respondents). Moreover, a higher forecasting performance is obtained using the soil moisture than rainfall due to the catchment memory $[35,73,74]$. The use of local knowledge to indicate the soil moisture conditions and relate them with agricultural planning is already implemented in our study areas. Farmers usually observe some trees and earthworms to indicate the wetness of the soils and time for sowing. We also note that no indicator is specifically used to predict the wetness and dryness of the soil. Farmers link 
the prediction of rain events associated with the prediction of soil wetness. There are many indicators that can be used to predict the rainy event, as found in literature [75-79].

\subsection{The Needs for an Information Service Based on Soil Moisture (CIS-SM)}

Although only a few farmers stated that soil moisture is an important variable for farming decision-making, many of them are aware of the concept of soil moisture. More importantly, farmers do consider soil moisture conditions in almost each rice production stage, from land preparation, sowing, fertilizer application, and even weed control (Figure 5). Farmers also wanted the soil moisture forecast information alongside rainfall forecast (Figure 6c). A CIS-SM that integrates the indigenous forecast knowledge with scientific forecast knowledge is of utmost importance to support farmers' decision-making. The integration between indigenous and scientific forecast knowledge will increase forecast resolution and skills and reduce recurring tensions between the two knowledge systems [78,79].

The available CISs only provide weather and climate information and soil moisture information is still not well implemented [26,28,80-82]. Development of CIS-SM remains a challenge because of various reasons: (1) there are only limited in situ soil moisture measurements across the globe, (2) weather forecast providers delivering soil moisture forecast products are very limited, and (3) analyzing soil moisture forecast tailored to specific locations and needs involves soil moisture modeling and measurements. There are some ways to overcome these challenges, for example the use of a remote sensing dataset e.g., [83,84] and a hydrological model e.g., [85,86] offers a new perspective for the development of CIS-SM. Another method to forecast soil moisture in a specific location is using a simple water balance model fed by weather forecast data and in situ soil moisture measurements, for example using the feel and appearance method as introduced in our study areas.

Developing CIS embedded with a soil moisture forecast advisory module (CIS-SM) will also provide economic and environmental benefits for smallholder farmers practicing rainfed agriculture. The CIS-SM will increase the smallholder farmers' income because, firstly, soil moisture forecast and advice can increase the annual yield by delivering information on actual and forecasted soil moisture conditions to avoid water shortage and/or excess water. When the harvest exceeds the food requirements for self-maintenance of the farmers and their families, smallholder farmers can sell the surplus to increase the farmer's capital. Secondly, adjusting agricultural practices based on the soil moisture condition allows farmers to spend less by avoiding re-sowing in case of failure, reduces use of fertilizer and pesticide and aids timely harvesting $[28,87]$. We also notice that many farmers in our study areas and in the sub-Saharan Africa, in general, have water pumps for irrigation [88]. CIS-SM is extremely important to these farmers because, with the right information, they can economize the fuel costs by using the pumps at the right time e.g., when the soil is dry and no precipitation is forecasted. The agricultural sector is currently responsible for $70 \%$ of worldwide water abstractions [89]. The soil moisture forecast advising tool, thus, could help smallholder farmers to increase the water-use efficiency of crops and in the end, will reduce the pressure of agriculture on available water resources.

\section{Conclusions}

Smallholder farmers in Northern Region of Ghana are engaged with small-scale rainfed agriculture and irrigation, where the success of their crops strongly depends on agricultural-related information, including weather forecasts. Some agricultural information, such as water availability, weather forecast, input prices, crop variety, disease control, market price, and soil moisture are obtained by farmers from many different sources. In general, farmers identified that the quality of agricultural-related information received by them is good. The main platforms where farmers receive agricultural-related information are radio and TV, where Information on water availability, weather forecast, and crop variability are regarded as most important. However, farmers do not always receive needed 
information on the soil moisture. Soil moisture is thus selected as important information only by a few farmers included in the study.

Our research highlights the role of soil moisture in daily farming practices. From the field interviews and FGDs, farmers consider soil moisture conditions in the agricultural decision-making activities at every stage. Many farmers are of the view that soil moisture information is highly important for fertilizer application, followed by sowing, land preparation, and weed control. The information on soil moisture, however, is not always available and even not accessible. Some farmers also rely on their indigenous knowledge to monitor the soil moisture conditions, associated with the right timing for sowing. Soil moisture forecast is ranked as the second critical information for farmers, after precipitation. Our study reveals that soil moisture information is crucial for farmers to conduct strategic and tactical decision-making in their daily farming activities. Moreover, farmers show an interest in obtaining soil moisture forecast information that could help them to increase the water-use efficiency and in the end, reduce the pressure on available water resources for agriculture. The results, therefore, suggest that further development of a CIS imbedded with a soil moisture advisory module (CIS-SM) is beneficial, particularly since it is important to develop a robust CIS.

Supplementary Materials: The following are available online at https:/ /www.mdpi.com/article/ 10.3390 /agronomy12020541/s1, The Supplementary Information comprises questionnaire that was used during interviews and forum group discussion as follows.

Author Contributions: S.J.S. and S.P. conceived and implemented the research. G.K.-B., B.Z.G., I.S. and E.v.S. contributed substantially to the study design, editing, and commenting on the article drafts for several rounds. B.M.J. and A.K.I. contributed to this article through extensive field work, data acquisition, and synthesis of field notes for this study. All authors have read and agreed to the published version of the manuscript.

Funding: This research is supported by the WAGRINNOVA project, which is funded by LEAP-Agri and co-financed by the European Union's EU Framework Programme for Research and Innovation Horizon 2020 under the ERA-NET-COFUND (grant agreement no. 727715).

Data Availability Statement: Data and scripts generated and/or analyzed during this study are available from the corresponding author on request.

Acknowledgments: The authors would like to thank all participants of the study for their contribution as without them the current study would not have been possible.

Conflicts of Interest: The authors declare no conflict of interest.

\section{References}

1. Wani, S.P.; Rockström, J.; Oweis, T.Y. Rainfed Agriculture: Unlocking the Potentia; Comprehensive Assessment of Water Management in Agriculture Series 7; International Crops Research Institute for the Semi-Arid Tropics (ICRISAT), International Water Management Institute (IWMI): Colombo, Sri Lanka, 2009; 310p.

2. Svendsen, M.; Ewing, M.; Msangi, S. Measuring Irrigation Performance in Africa; IFPRI Discussion Paper 00894; International Food Policy Research Institute: Washington, DC, USA, 2009.

3. Biazin, B.; Sterk, G.; Temesgen, M.; Abdulkedir, A.; Stroosnijder, L. Rainwater harvesting and management in rainfed agricultural systems in sub-Saharan Africa-A review. Phys. Chem. Earth 2012, 47-48, 139-151. [CrossRef]

4. World Bank. Spurring Agricultural and Rural Development. In Can Africa Claim the 21st Century? World Bank: Washington, DC, USA, 2000; pp. 170-207.

5. Rockström, J.; Falkenmark, M. Agriculture: Increase water harvesting in Africa. Nature 2015, 519, 283. [CrossRef] [PubMed]

6. Shimeles, A.; Verdier-Chouchane, A.; Boly, A. Introduction: Understanding the Challenges of the Agricultural Sector in SubSaharan Africa. In Building a Resilient and Sustainable Agriculture in Sub-Saharan Africa; Palgrave Macmillan: Cham, Switzerland; London, UK, 2018; pp. 1-12.

7. FAO. Socio-Economic Context and Role of Agriculture, Country Fact Sheet on Food and Agriculture Policy Trends Ghana; Food and Agriculture Organization of the United Nations: Rome, Italy, 2015. Available online: https://www.fao.org/3/i4490e/i4490e.pdf (accessed on 20 November 2021).

8. GSS. 2015 Labour Force Report, Ghana Statistical Service. Available online: https://www2.statsghana.gov.gh/docfiles/ publications/Labour_Force/LFS\%20REPORT_final_21-3-17.pdf (accessed on 10 November 2021). 
9. Yaro, J.A. The perception of and adaptation to climate variability/change in Ghana by small-scale and commercial farmers. Reg. Environ. Chang. 2013, 13, 1259-1272. [CrossRef]

10. Gbangou, T.; Ludwig, F.; Van Slobbe, E.; Hoang, L.; Kranjac-Berisavljevic, G. Seasonal variability and predictability of agrometeorological indices: Tailoring onset of rainy season estimation to meet farmers' needs in Ghana. Clim. Serv. 2019, 14, 19-30. [CrossRef]

11. Derbile, E.K.; Abdul-Moomin, A.; Yakubu, I. Local knowledge and community-based assessment of environmental change in Ghana. Ghana J. Geogr. 2016, 8, 59-83.

12. Phillips, J.; Makaudze, E.; Unganai, L. Current and Potential Use of Climate Forecasts for Resource-Poor Farmers in Zimbabwe. In Impacts of El Niño and Climate Variability in Agriculture; Special Publication no. 63 ed.; American Society of Agronomy: Madison, WI, USA, 2001; pp. 87-100.

13. Patt, A.; Suarez, P.; Gwata, C. Effects of seasonal climate forecasts and participatory workshops among subsistence farmers in Zimbabwe. Proc. Natl. Acad. Sci. USA 2005, 102, 12623-12628. [CrossRef]

14. Roncoli, C.; Jost, C.; Kirshen, P.; Sanon, M.; Ingram, K.T.; Woodin, M.; Somé, L.; Ouattara, F.; Sanfo, B.J.; Sia, C.; et al. From accessing to assessing forecasts: An end-to-end study of participatory climate forecast dissemination in Burkina Faso (West Africa). Clim. Chang. 2009, 92, 433-460. [CrossRef]

15. Okello, J.J.; Kirui, O.K.; Njiraini, G.W.; Gitonga, Z.M. Drivers of use of information and communication technologies by farm households: The case of smallholder farmers in Kenya. J. Agric. Sci. 2012, 4, 111-124. [CrossRef]

16. Etwire, P.M.; Buah, S.; Ouédraogp, M.; Zougmoré, R.; Partey, S.T.; Martey, E.; Dayamba, S.D.; Bayala, J. An assessment of mobile phone-based dissemination of weather and market information in the upper West region of Ghana. Agric. Food Secur. 2017, 6, 1-9. [CrossRef]

17. Paparrizos, S.; Smolenaars, W.; Gbangou, T.; van Slobbe, E.; Ludwig, F. Verification of Weather and Seasonal Forecast Information Concerning the Peri-Urban Farmers' Needs in the Lower Ganges Delta in Bangladesh. Atmosphere 2020, 11, 1041. [CrossRef]

18. McNew, K.P.; Mapp, H.P.; Duchon, C.E.; Merritt, E.S. Sources and uses of weather information for agricultural decision makers. Bull. Am. Meteorol. Soc. 1991, 72, 491-498. [CrossRef]

19. Letson, D.; Llovet, I.; Podestá, G.; Royce, F.; Brescia, V.; Lema, D.; Parellada, G. User perspectives of climate forecasts: Crop producers in Pergaminao, Argentina. Clim. Res. 2001, 19, 57-67. [CrossRef]

20. Patt, A.; Gwata, C. Effective seasonal climate forecast application: Examining constraints for subsistence farmers in Zimbabwe. Glob. Env. Chang. 2002, 12, 185-195. [CrossRef]

21. Artikov, I.; Hoffman, S.J.; Lynne, G.D.; Zillig, L.M.P.; Hu, Q.; Tomkins, A.J.; Hubbard, K.G.; Hayes, M.J.; Waltman, W. Understanding the Influence of Climate Forecasts on Farmer Decisions as Planned Behavior. J. Appl. Meteorol. Climatol. 2006, 45, 1202-1214. [CrossRef]

22. Manyanhaire, I.O.; Miriam, C. Integrating indigenous knowledge systems into climate change interpretation: Perspectives relevant to Zimbabwe. Greener J. Educ. Res. 2015, 5, 27-36. [CrossRef]

23. Kumar, U.; Werners, S.; Paparrizos, S.; Datta, D.K.; Ludwig, F. Hydroclimatic information needs of smallholder farmers in the lower Bengal Delta, Bangladesh. Atmosphere 2020, 11, 1009. [CrossRef]

24. Vogel, J.; Letson, D.; Herrick, C. A framework for climate services evaluation and its application to the Caribbean Agrometeorological Initiative. Clim. Serv. 2017, 6, 65-76. [CrossRef]

25. Nyamekye, A.B.; Dewulf, A.; van Slobbe, E.; Termeer, K. Information systems and actionable knowledge creation in rice-farming systems in Northern Ghana. Afr. Geogr. Rev. 2020, 39, 144-161. [CrossRef]

26. Vaughan, C.; Hansen, J.; Roudier, P.; Watkiss, P.; Carr, E. Evaluating agricultural weather and climate services in Africa: Evidence, methods and a learning agenda. WIREs Clim. Chang. 2019, 10, e586. [CrossRef]

27. Gbangou, T.; Ludwig, F.; van Slobbe, E.; Greuell, W.; Kranjac-Berisavljevic, G. Rainfall and dry spell occurrence in Ghana: Trends and seasonal predictions with a dynamical and a statistical model. Theor. Appl. Climatol. 2020, 141, 371-387. [CrossRef]

28. Kumar, U.; Werners, S.E.; Paparrizos, S.; Datta, D.K. Co-producing climate information services with smallholder farmers in the Lower Bengal Delta: How forecast visualization and communication support farmers' decision-making. Clim. Risk Manag. 2021, 33, 100346. [CrossRef]

29. Kang, Y.; Khan, S.; Ma, X. Climate change impacts on crop yield, crop water productivity and food security-A review. Prog. Nat. Sci. 2009, 19, 1665-1674. [CrossRef]

30. Carrao, H.; Russo, S.; Supulcre-Canto, G.; Barbosa, P. An empirical standardized soil moisture index for agricultural drought assessment from remotely sensed data. Int. J. App. Earth Observ. Geol. 2016, 48, 74-84. [CrossRef]

31. Rossato, L.; dos Santos Alvalá, R.C.; Marengo, J.A.; Zeri, M.; do Amaral Cunha, A.P.M.; Pires, L.B.M.; Barbosa, H.A. Impact of soil moisture on crop yields over Brazilian semiarid. Front. Environ. Sci. 2017, 5, 73. [CrossRef]

32. Gałęzewski, L.; Jaskulska, I.; Jaskulski, D.; Lew, owski, A.; Szplowska, A.; Wilczek, A.; Szczepanczyk, M. Analysis of the need for soil moisture, salinity and temperature sensing in agriculture: A case study in Poland. Sci. Rep. 2021, 11, 1666. [CrossRef]

33. Asbjornsen, H.; Goldsmith, G.R.; Alvaradobarrientos, M.S.; Rebel, K.; Osch, F.P.V.; Rietkerk, M.; Chen, J.; Gotsch, S.; Tobón, C.; et al. Ecohydrological advances and applications in plant-water relations research: A review. J. Plant Ecol. 2011, 4, 3-22. [CrossRef]

34. Wang, C.; Fu, B.; Zhang, L.; Xu, Z. Soil moisture-plant interactions: An ecohydrological review. J. Soils Sediments 2019, 19, 1-9. [CrossRef] 
35. Sutanto, S.J.; Wetterhall, F.; Van Lanen, H.A.J. Hydrological drought forecasts outperform meteorological drought forecasts. Environ. Res. Lett. 2020, 15, 084010. [CrossRef]

36. Sutanto, S.J.; Van Lanen, H.A.J. Catchment memory explains hydrological drought forecast performance. Sci. Rep. 2022, 12, 2689. [CrossRef]

37. Kothari, C.R. Research Methodology: Methods and Techniques; E-book; New Age International: New Delhi, India, 2004.

38. Maxwell, J.A. Qualitative Research Design: An Interactive Approach; E-book; Sage: London, UK, 2012; Volume 41

39. Jebb, A.T.; Parrigon, S.; Woo, S.E. Exploratory data analysis as a foundation of inductive research. Hum. Resour. Manag. Rev. 2017, 27, 265-276. [CrossRef]

40. Angelucci, F.; Asante-Poku, A.; Anaadumba, P. Analysis of Incentives and Disincentives for Rice in Ghana; Technical Notes Series; FAO: Rome, Italy, 2013.

41. Abdul-Rahaman, I.; Owusu-Sekyere, E. Climate variability and sustainable food production: Insights from north-eastern Ghana Ghana J. Geogr. 2017, 9, 67-89.

42. McSweeney, C.; New, M.; Lizcano, G. UNDP Climate Variability. Country Profiles: Ghana. 2006. Available online: https: / / digital.library.unt.edu/ark:/67531/metadc226664/ (accessed on 25 November 2021).

43. Yiran, G.A.B.; Kusimi, J.M.; Kufogbe, S.K. A synthesis of remote sensing and local knowledge approaches in land degradation assessment in the Bawku East District, Ghana. Int. J. Appl. Earth Obs. Geoinf. 2012, 14, 204-213. [CrossRef]

44. Quaye-Ballard, J.A.; Okrah, T.M.; Andam-Akorful, S.A.; Awotwi, A.; Antwi, T.; Osei-Wusu, W.; Tang, X.; Quaye-Ballard, N.L. Spatiotemporal dynamics of rainfall in Upper East Region of Ghana, West Africa, 1981-2016. SN Appl. Sci. 2020, 2, 1675. [CrossRef]

45. Nyadzi, E. Climate variability since 1970 and farmers' observations in Northern Ghana. Sustain. Agric. Res. 2016, 5 . [CrossRef]

46. Owusu, K.; Waylen, P. Trends in spatio-temporal variability in annual rainfall in Ghana (1951-2000). Weather 2009, 64, 115-120. [CrossRef]

47. Nyadzi, E. Best of both worlds: Co-Producing Climate Services that Integrate Scientific and Indigenous Weather and Seasonal Climate Forecast for Water Management and Food Production in Ghana. Ph.D. Thesis, Wageningen University, Wageningen, The Netherlands, 2020.

48. Ansah, T.; Nagbila, D.A. Utilization of local trees and shrubs for sustainable livestock production in the Talensi-Nabdam District of the Upper East Region of Ghana. Livest. Res. Rural. Dev. 2011, 23. [CrossRef]

49. Klocke, N.L.; Fischbach, P.E. G84-690 Estimating Soil Moisture by Appearance and Feel, Historical Materials from University of Nebraska-Lincoln Extension, 1201, 1984. Available online: https:/ / digitalcommons.unl.edu/extensionhist/1201/ (accessed on 31 December 2021).

50. Guarte, J.M.; Barrios, E.B. Estimation under purposive sampling. Commun. Stat. -Simul. Comput. 2006, 35, 277-284. [CrossRef]

51. Etikan, I.; Musa, S.A.; Alkassim, R.S. Comparison of convenience sampling and purposive sampling. Am. J. Theor. Appl. Stat. 2016, 5, 1-4. [CrossRef]

52. Wolfinger, N.H. On writing fieldnotes: Collection strategies and background expectancies. Qual. Res. 2002, 2, 85-93. [CrossRef]

53. Van Maanen, J. Tales of the Field: On Writing Ethnography, 2nd ed.; University of Chicago Press: Chicago, IL, USA, 2011; 232p.

54. Gbangou, T.; Sarku, R.; van Slobe, E.; Ludwig, F.; Kranjac-Berisavljevic, G.; Paparrizos, S. Coproducing Weather Forecast Information with and for Smallholder Farmers in Ghana: Evaluation and Design Principles. Atmosphere 2020, 11, 902. [CrossRef]

55. García, Z.; Nyberg, J.; Saadat, S.O. Agriculture, Trade Negotiations and Gender; Food and Agriculture Organization of the United Nations: Rome, Italy, 2006. Available online: https://www.fao.org/3/a0493e/a0493e00.htm\#Contents (accessed on 20 January 2022).

56. Britwum, A.O.; Akorsu, A.D. Qualitative Gender Evaluation of Agricultural Intensification Practices in Northern Ghana; Institute of Tropical Agriculture: Ibadan, Nigeria, 2016; 62p.

57. FAO. Gender Inequalities in Rural Employment in Ghana-An Overview; Food and Agriculture Organization of the United Nations: Rome, Italy, 2012. Available online: https:/ / www.fao.org/3/ap090e/ap090e00.pdf (accessed on 20 January 2022).

58. OECD. Working Age Population (Indicator). Available online: https://http://doi.org/10.1787/d339918b-en (accessed on 6 January 2022).

59. Kuivanen, K.S.; Alvarez, S.; Michalscheck, M.; Adjei-Nsiah, S.; Descheemaeker, K.; Mellon-Bedi, S.; Groot, J.C.J. Characterising the diversity of smallholder farming system and their constraints and opportunities for innovation: A case study from the Northern Region, Ghana. NJAS-Wagening. J. Life Sci. 2016, 78, 153-166. [CrossRef]

60. PHC. 2010 Population and Housing Census, National Analytical Report, Ghana Statistical Service, May 2013. Available online: https://statsghana.gov.gh/gssmain/fileUpload/pressrelease/2010_PHC_National_Analytical_Report.pdf (accessed on 21 January 2022).

61. Krell, N.T.; Giroux, S.A.; Guido, Z.; Hannah, C.; Lopus, S.E.; Caylor, K.K.; Evans, T.P. Smallholder farmers' use of mobile phone services in central Kenya. Clim. Dev. 2021, 13, 215-227. [CrossRef]

62. Kumar, U.; Werners, S.; Roy, S.; Ashraf, S.; Hoang, L.P.; Datta, D.K.; Ludwig, F. Role of information in Farmers' response to weather and water related stresses in the lower Bengal Delta, Bangladesh. Sustainability 2020, 12, 6598. [CrossRef]

63. World Bank. Information and Communications for Development 2018: Data-Driven Development; Tech. Report No. 128301; World Bank: Washington, DC, USA, 2018; 177p. 
64. Wyche, S.; Olson, J. Gender, mobile and mobile internet-Kenyan women's rural realities, mobile internet access and "Africa rising". Inf. Technol. Int. Dev. 2018, 14, 33-47.

65. Qiang, C.Z.; Kuek, S.C.; Dymond, A.; Esselaar, S. Mobile Applications for Agriculture and Rural Development; Report No: 96226-GLB; ICT Sector Unit, World Bank: Washington, DC, USA, 2012.

66. Zhang, Y.; Yu, L. Information for social and economic participation: A review of related research on the information needs and acquisition of rural Chinese. Int. Inf. Libr. Rev. 2009, 41, 63-70. [CrossRef]

67. Babu, S.C.; Glendening, C.J.; Anseso-Okoye, K.; Govindarajan, S.K. Farmers' Information Needs and Search Behaviours: Case Study in Tamil Nadu, India; Discussion paper 01166; International Food Policy Research Institute: Washington, DC, USA, 2012; 48p.

68. Benard, R.; Dulle, F.; Ngalapa, H. Assessment of Information Needs of Rice Farmers in Tanzania; A Case Study of Kilombero District, Morogoro. Libr. Philos. Pract. 2014, 1071. Available online: http://digitalcommons.unl.edu/libphilprac/1071 (accessed on 21 January 2022).

69. Nyadzi, E.; Werners, E.S.; Biesbroek, R.; Long, P.H.; Franssen, W.; Ludwig, F. Verification of seasonal climate forecast toward hydroclimatic information needs of rice farmers in Northern Ghana. Weather Clim. Soc. 2019, 11, 127-142. [CrossRef]

70. Nyamekye, A.B.; Nyadzi, E.; Dewulf, A.; Werners, S.; van SLobe, E.; Biesbroek, R.G.; Termeer, C.J.A.M.; Ludwig, F. Forecast probability, lead time and farmer decision-making in rice farming system in Northern Ghana. Clim. Risk Manag. 2021, $31,100258$. [CrossRef]

71. Vitart, F. Monthly forecasting at ECMWF. Mon. Weather Rev. 2004, 132, 2761-2779. [CrossRef]

72. Yuan, X.; Wood, E.F.; Roundy, J.K.; Pan, M. CFSv2-based seasonal hydroclimatic forecasts over the conterminous United States. J. Clim. 2013, 26, 4828-4847. [CrossRef]

73. Van Lanen, H.A.; Wanders, N.; Tallaksen, L.M.; Van Loon, A.F. Hydrological drought across the world: Impact of climate and physical catchment structure. Hydrol. Earth Syst. Sci. 2013, 17, 1715-1732. [CrossRef]

74. Van Loon, A.F.; Laaha, G. Hydrological drought severity explained by climate and catchment characteristics. J. Hydrol. 2015, 526, 3-14. [CrossRef]

75. Kalanda-Joshua, M.; Ngongondo, C.; Chipeta, L.; Mpembeka, F. Integrating indigenous knowledge with conventional science: Enhancing localized climate and weather forecasts in Nessa, Mulanje, Malawi. Phys. Chem. Earth 2011, 36, 996-1003. [CrossRef]

76. Vilakazi, B.; Zangeni, R.; Mafongoya, P. Indigenous strategies used by selected farming communities in KwaZulu Natal, South Africa, to manage soil, water and climate extremes and to make weather predictions. Land Degrad. Dev. 2019, 30, 1999-2008. [CrossRef]

77. Radeny, M.; Desalegn, A.; Mubiru, D.; Kyazze, F.; Mahoo, H.; Recha, J.; Kimeli, P.; Solomon, D. Indigenous knowledge for seasonal weather and climate forecasting across East Africa. Clim. Chang. 2019, 156, 509-526. [CrossRef]

78. Gbangou, T.; van Slobe, E.; Ludwig, F.; Kranjac-Berisavljevic, G.; Paparrizos, S. Harnessing local forecasting knowledge on weather and climate in Ghana: Documentation, skill and integration with scientific forecasting knowledge. Weather Clim. Soc. 2021, 13, 23-37. [CrossRef]

79. Nyadzi, E.; Werners, S.E.; Biesbroek, R.; Ludwig, F. Techniques and skills of indigenous weather and seasonal climate forecast in northern Ghana. Clim. Dev. 2021, 13, 551-562. [CrossRef]

80. Kadi, M.; Njau, L.N.; Mwikya, J.; Kamga, A. The State of Climate Information Services for Agriculture and Food Security in East African Countries. CCAFS Working Paper No. 5, Copenhagen, Denmark. Available online: www.ccafs.cgiar.org (accessed on 15 December 2021).

81. Vaughan, C.; Dessai, S. Climate services for society: Origins, institutional arrangements and design elements for an evaluation framework. Wiley Interdiscip. Rev. Clim. Chang. 2014, 5, 587-603. [CrossRef]

82. Dayamba, D.S.; Ky-Dembele, C.; Bayala, J.; Dorward, P.; Clarkson, G.; Sanogo, D.; Mamadou, L.D.; Traoré, I.; Diakité, A.; Nenkam, A.; et al. Assessment of the use of participatory integrated climate services for agriculture (PICSA) approach by farmers to manage climate risk in Mali and Senegal. Clim. Serv. 2018, 12, 27-35. [CrossRef]

83. Fang, B.; Lakshmi, V. Soil moisture at watershed scale: Remote sensing techniques. J. Hydrol. 2014, 516, 258-272. [CrossRef]

84. Mohanty, B.P.; Cosh, M.H.; Lakshmi, V.; Montzka, C. Soil moisture remote sensing: State-of-the-science. Vadose Zone J. 2017, 16, 1-9. [CrossRef]

85. López-López, P.; Sutanudjaja, E.H.; Schellekens, J.; Sterk, G.; Bierkens, M.F.P. Calibration of a large-scale hydrological model using satellite-based soil moisture and evapotranspiration products. Hydrol. Earth Syst. Sci. 2017, 21, 3125-3144. [CrossRef]

86. Wanders, N.; Bierkens, M.F.P.; Jong, S.M.; Roo, A.; Karssenberg, D. The benefits of using remotely sensed soil moisture in parameter identification of large-scale hydrological models. Water Resour. Res. 2014, 50, 6874-6891. [CrossRef]

87. Ouédraogo, M.; Zougmoré, R.; Barry, S.; Somé, L.; Baki, G. The Value and Benefits of Using Seasonal Climate Forecasts in Agriculture: Evidence from Cowpea and Sesame Sectors in Climate-Smart Villages of Burkina Faso; CCAFS Info Note: Copenhagen, Denmark, 2015; pp. 1-4.

88. De Fraiture, C.; Giordano, M. Small private irrigation: A thriving but overlooked sector. Agric. Water Manag. 2014, 131, 167-174. [CrossRef]

89. Roy, R.N.; Finck, A.; Blair, G.J.; Tandon, H.L.S. Plant Nutrition for Food Security: A Guide for Integrated Nutrient Management. FAO Fertilizer and Plant Nutrition Bulletin, 16. Available online: https:/ /www.fao.org/fileadmin/templates/soilbiodiversity/ Downloadable_files/fpnb16.pdf (accessed on 24 November 2021). 